\title{
Born-digital: The Internationalisation Path of Digital Firms
}

\author{
Stella Mingzhu Ye \\ Massey University \\ S.M.Ye@massey.ac.nz
}

\author{
Yuanfei Kang \\ Massey University \\ Y.Kang@massey.ac.nz
}

\author{
Joanna Scott-Kennel \\ University of Waikato \\ joanna.scott-kennel@,waikato.ac.nz
}

\begin{abstract}
While digital firms are playing an increasingly important role in the world economy, their international expansion remains an emergent topic for international business researchers. We still lack a clear understanding of the characteristics and patterns of internationalisation by digital firms. This study aims to address this research gap by examining the path of digital firms' international expansion. Applying the research methods of tabulation analysis and mini case study, our study reveals that digital firms expand into foreign markets in a way that significantly differs from conventional brick-and-mortar firms, thus questioning explanations provided by extant internationalisation theories. Three patterns of digital firms' internationalization are identified. Based on analysis of archival data, this study contributes to theoretical development of internationalisation theory and provides guidance to managers of digital firms creating and implementing international expansion strategies.
\end{abstract}

Keywords: Digital firms, international expansion, digital technologies, network effect, digital platform, e-commerce

\section{Introduction}

With the development of digital technologies, digitalisation of business has become an everyday phenomenon and digital firms play an increasingly important role in the world economy. Application of digital technologies, such as the Internet and mobile devices, is disrupting traditional business models, removing established incumbent firms, and reconfiguring firms' organisational structures $[2 ; 5 ; 8 ; 26 ; 32]$. One of the major emerging changes in business activity derived from digital technologies is rapid and proactive international expansion via digital platforms. As digital technologies can substantially reduce the cost of expanding business operations across national borders, and reduce the time taken to internationalise, many digital firms have often been characterised as 'born global' firms $[1 ; 16$; 19]. Although many digital firms are 'born global' in that they grow and internationalise rapidly from their inception, studies of digital firms have so far rarely examined their international expansion [15; 16]. Thus, this paper seeks to explore the internationalisation path of the unique 'born digital' firm.

Research on digital firms' international expansion is still in the emergent phase in the international business discipline [12]. Existing mainstream international expansion theories, such as the Uppsala model, are generated from the experience of traditional brick-and-mortar firms. For example, the Uppsala model suggests that firms' international expansion is driven by and dependent on their resource 
commitments in foreign markets. With dramatically changed business practices in the digital age, constant transformation of global business forms has outpaced scholarly knowledge on the international expansion of digital firms. Therefore, it is not clear whether such internationalisation theories can be satisfactorily applied to explain international expansion of digital firms.

Given these circumstances, the following questions guided our research: what are the critical characteristics of digital firms, and how is their international expansion path associated with these characteristics? More specifically, this study aims to provide an understanding of the international expansion path of the digital firms, to inform both extant theory and managerial executives developing strategy for global growth.

\section{Digital firms and their characteristics}

Digital firms rely on digital infrastructure provided by information and communications technology (ICT) firms, and base their production, operating and delivery processes on the internet [15]. Thus, digital firms need to be distinguished from ICT firms. Based on the categorisation by UNCTAD [28; 29], ICT firms include manufacturers of ICT hardware and components, such as Samsung and Toshiba; firms providing software and services such as Microsoft and Oracle; and telecom firms that provide the infrastructure for communication, such as Vodafone and Deutsche Telekom. In contrast, building on the enabling digital infrastructure provided by ICT firms, digital firms rely on the internet for their operations $[20 ; 30]$. There are four types of digital firms including internet platform firms, digital solution firms, e-commerce firms, and digital content firms [29]. Table 1 provides a summary of types of digital firms.
Table 1: Types of Digital Firms

\begin{tabular}{|l|l|l|}
\hline Type & \multicolumn{1}{|c|}{ Subcategory } & $\begin{array}{l}\text { Example } \\
\text { firm }\end{array}$ \\
\hline $\begin{array}{l}\text { Internet } \\
\text { platforms }\end{array}$ & $\begin{array}{l}\text { Search engines; Social } \\
\text { networks; Other platforms }\end{array}$ & $\begin{array}{l}\text { Facebook, } \\
\text { eBay, } \\
\text { LinkedIn }\end{array}$ \\
\hline $\begin{array}{l}\text { Digital } \\
\text { solutions }\end{array}$ & $\begin{array}{l}\text { Electronic payments; } \\
\text { Other digital solutions }\end{array}$ & $\begin{array}{l}\text { PayPal, } \\
\text { NetApp, } \\
\text { GoDaddy }\end{array}$ \\
\hline $\begin{array}{l}\text { E- } \\
\text { commerce }\end{array}$ & $\begin{array}{l}\text { Online internet retailers; } \\
\text { Other e-commerce }\end{array}$ & $\begin{array}{l}\text { Amazon, } \\
\text { Alibaba }\end{array}$ \\
\hline $\begin{array}{l}\text { Digital } \\
\text { content }\end{array}$ & $\begin{array}{l}\text { Digital media; Games } \\
\text { Info and data }\end{array}$ & $\begin{array}{l}\text { Tencent, } \\
\text { Netflix }\end{array}$ \\
\hline
\end{tabular}

Data source: UNCTAD (2019)

It is worth noting that while we can distinguish four types of digital firms, operations of these firms are likely to overlap with each other across the different types. For example, as an internet platform firm, Facebook has also been involved in ecommerce through its subsidiary, Facebook Marketplace. Tencent owns and operates Wechat, the most popular social media platform in China, in which e-commerce businesses are embedded. Amazon and Alibaba are the two giants of the ecommerce field, but both have spread their business scope into the digital solutions and digital content areas.

Digital firms have several common characteristics [20]. First, they leverage the advantages of digital technologies as their foundation and are built on digital infrastructure such as computers, mobile devices, and the internet network $[17 ; 18$; 23]. Digital infrastructure provides digital firms with an identifiable online presence that is in (cyber) 'space'. Digital firms also have physical 'place' such as offices, warehousing, robotics, or data centres [16]. This 'space-place' relationship is one characteristic that distinguishes digital firms from traditional manufacturing firms. While similar to traditional manufacturing firms in terms of the need for capital investment in physical operations (i.e., plant), digital firms tend to have much higher ratio of internet intensity to physical assets than traditional firms. 
Second, digital firms tend to be born digital and to operate online, and thus are virtual-permeated [30]. Digital firms rely on digital infrastructure to develop and accrue communication, collaboration and computing capabilities. These capabilities allow the firm to create, market, and sell its product offering online through a digital business model. Built on digital infrastructure, the instantaneous and global internet network provides instant access to end-users, so that products and services of the digital firms engage directly with their customers and other stakeholders $[7 ; 30]$. The virtual-permeated digital business model represents another distinctive characteristic of digital firms. This distinction also means that firms with a physical market offering, even if they have adopted digital technologies into their existing business processes and have a high degree of digitalisation, are not digital firms. For example, Volkswagen has used artificial intelligence to predict flows and omissions in the production process, and is thus in the process of using big data to establish its global users-network. However, such innovations merely demonstrate that Volkswagen is digitalising but is not a digital firm.

Third, digital firms are network oriented. Digital technologies provide digital firms the means to closely integrate with many different and potentially complementary actors within their networks. This extends the firm's network from conventional business relationships to include end-users, local content producers, venture capital providers and other firms that offer complementary assets [24]. Products and services of digital firms are more likely to be intangible, and thus their business transactions are less constrained by geographical distance, rather they rely on the size of their user-networks, thus generating a network effect. For digital firms, the value of digital networks created for an individual user increases with the total number of network users. The more users can a digital firm have, the more value it can provide for potential users, and thus the more it is able to attract new users [7]. This characteristic of network effect for digital firms can lead to a 'chicken-and-egg' problem: the difficulty lies in attracting users to a digital firm that only creates value once a robust user base exists. For example, YouTube, which offers a video sharing platform, will only attract viewers once a sizable collection of videos has been uploaded, but content producers are willing to upload videos only when there is substantial viewer audience [24]. This mutually reinforcing feedback loop can translate an early lead in network size, into a lasting competitive advantage. Thus, firstmover advantage presents a strong feature of digital firms and being a first mover can result in 'the winner-takes-all' scenario [11; 27]. For instance, it is highly difficult for newcomers to challenge Facebook's competitive position in the social media platform field, because it has already developed billions monthly active users, unless the new challenger can identify and penetrate and out-perform in another niche in the field (e.g., WhatsApp chat).

\section{Method}

We took a three-step approach to analyse the international expansion path of the digital firms. First, based on the database of United Nations Conference on Trade and Development [28], we randomly selected 25 firms from the top 100 digital multinational enterprises (MNEs). We collected data for the selected digital MNEs from online databases such as Orbis BvD along the dimensions of the sample firm's profile and growth indexes, such as time since establishment, country of origin, total assets, revenue turnover and employee numbers, in order to analyse the characteristics of digital MNE firms. Then, we ran a cross-tabulation analysis regarding the sampled firms' international expansion along the two dimensions of their home country and major host markets for overseas operations. We took the country of 
incorporation as the firm's home country. If the sampled firm was registered in locations associated with co-called tax havens, such as the British Virgin Islands, and Bermuda, we took the country of business origin as the place of incorporation. Further, we selected two firms, Airbnb and Kuaishou, as 'mini' cases characteristic of digital internationalisation.

\section{Path of digital firms' international expansion - Data \& Cases}

Table 2 presents a data summary of the selected digital firms used for our analysis.

Table 2: Internationalisation information of selected digital MNEs

\begin{tabular}{|c|c|c|c|c|c|c|}
\hline Digital MNEs & $\begin{array}{l}\text { Total assets } \\
\text { (USD) }\end{array}$ & $\begin{array}{l}\text { Number of } \\
\text { employees }\end{array}$ & $\begin{array}{c}\text { Home } \\
\text { country* }\end{array}$ & \multicolumn{3}{|c|}{ Top three host countries } \\
\hline Alphabet & $275,909,000$ & 118,899 & US & UK & Canada & Ireland \\
\hline Facebook & $133,376,000$ & 44,942 & US & Ireland & Denmark & Singapore \\
\hline eBay & $18,174,000$ & 13,300 & US & Luxembourg & China & Germany \\
\hline Groupon & $1,586,743$ & 6,345 & US & UK & Australia & Germany \\
\hline LinkedIn & $7,600,304$ & 1,611 & Ireland & US & UK & Germany \\
\hline Naver & $10,623,188$ & - & Korea & Japan & HK, S.A. R & Taiwan \\
\hline Red Hat & - & - & US & UK & Canada & Netherlands \\
\hline Match Group & $4,097,408$ & 8,700 & US & UK & Ireland & Canada \\
\hline $\begin{array}{l}\text { Automatic Data } \\
\text { Processing }\end{array}$ & $41,887,700$ & 58,000 & US & UK & Netherlands & Italy \\
\hline First Data & - & - & US & UK & Canada & Ireland \\
\hline PayPal & $51,333,000$ & 23,200 & US & UK & Luxembourg & Canada \\
\hline Workday & $6,816,365$ & 12,200 & US & Canada & Japan & UK \\
\hline VeriSign & $1,854,009$ & 872 & US & Switzerland & UK & India \\
\hline ServiceNow & $6,022,430$ & 10,371 & US & India & Israel & Australia \\
\hline Amazon & $225,248,000$ & 798,000 & US & Germany & UK & Canada \\
\hline Alibaba Group & $185,117,799$ & 117,600 & China & HK, S.A. R & US & Singapore \\
\hline Priceline Group & $21,402,000$ & 26,400 & US & UK & Netherlands & Singapore \\
\hline Criteo & $1,790,384$ & 2,755 & France & US & Japan & Australia \\
\hline Copart & $2,547,617$ & 7,327 & US & UK & Germany & Canada \\
\hline Yoox Net-a-Porter Grp & $3,442,848$ & 1,751 & Italy & UK & Switzerland & US \\
\hline Comcast & $263,414,000$ & 190,000 & US & UK & Australia & Germany \\
\hline Time Warner & 147,986 & 56,260 & UK & Netherlands & Mexico & Germany \\
\hline Entertainment One & - & - & Canada & US & UK & Ireland \\
\hline Verint Systems & $3,016,058$ & 6,500 & US & UK & Israel & Cyprus \\
\hline FactSet Research Systems & $1,560,130$ & 9,681 & US & UK & France & Germany \\
\hline
\end{tabular}

Source: Top 100 digital list UNCTAD, 2017 and Orbis BvD.

Note: Home country is the firm's country of incorporation, unless this is a tax haven, then country of origin is provided instead.

Host countries (excluding tax havens) are ranked by number of subsidiaries. 
Airbnb Inc. is an US-based digital media company founded by three entrepreneurs in 2008. Airbnb provides a digital platform for rental accommodation, specialising in the niche market of proving digital connection between travellers and accommodation owners with vacant rooms. Airbnb's business model is fundamentally different from the traditional non-digital travel agencies or room-booking platforms. Through the Internet and mobile apps, the platform has enabled Airbnb's online users to publish and search rental information about vacation rooms and to complete online booking procedures independently, bypassing intermediary agencies.

Airbnb has established 18 ultimately owned overseas subsidiaries in ten countries (see Table 3). In terms of foreign direct investment, the international path of Airbnb is highly concentrated in developed countries, particularly the United Kingdom, Canada and France. Key offshore offerings include the digital platform, payment service, computer software etc.

Table 3: Subsidiary distribution of Airbnb

\begin{tabular}{|l|c|}
\hline Country & $\begin{array}{c}\text { Number of } \\
\text { subsidiaries }\end{array}$ \\
\hline Australia & 1 \\
\hline Brazil & 1 \\
\hline Canada & 3 \\
\hline France & 3 \\
\hline India & 1 \\
\hline Italy & 1 \\
\hline Luxembourg & 1 \\
\hline Singapore & 1 \\
\hline Spain & 1 \\
\hline The United Kingdom & 5 \\
\hline
\end{tabular}

Data source: Orbis BvD

Based on the online communication between social media network users, industry disruptor Airbnb has changed the prevailing business model from business to customer into customer to customer.
Accommodation available via Airbnb are provided by individual property owners, and thus is more diverse and localised. Moreover, users - both travellers and room owners - can share their feedback regarding travel accommodation as well as travel tips. As a result, Airbnb has been able to serve a highly specialised market niche for affordable, self-booked travel and expand into foreign markets at much lower costs than traditional travel and accommodation agencies. In less than ten years from its establishment, Airbnb's services have expanded into 191 countries or regions and has more than 150 million registered users.

Kuaishou (literal meaning 'quick hand' in Chinese), offers an online platform for short-video sharing and livestreaming. Established in Beijing, China, in 2011 by two former Google employees, within four years Kuaishou developed a strong network of online users and cultivated several hundred million subscribers. In 2020, the company's initial public offering on the Hong Kong Stock Exchange was the world's largest internet IPO since Uber's in 2019.

Focused on the specific niche market of short video sharing, Kuaishou expanded internationally from the outset, gaining considerable popularity within a few years. A technical team has been established in Singapore, with plans to launch products in Indonesia and India. By 2021, approximately 300 million daily active users spent 86 minutes per day on the Kuaishou platform, whose Apps had topped the 'Most Downloaded' lists by both Google Play and Apple App Store in eight foreign countries [4].

Kuaishou is a typical 'born digital' company [16], which generates data, fast tracks technical change, interfaces new ideas with users, and explores new markets in ways that differ from conventional brickand-mortar firms. In 2020, revenue had reached USD6.3 billion, with employees nearing 20,000. 


\section{Analysis and discussion}

Based on the identification of key characteristics and patterns demonstrated in digital firms' international expansion, we develop an initial conceptual framework of digital firm internationalization path (Figure 1). Key characteristics are presented top and bottom of the framework, as influences on the process, motivations (primarily market/asset-seeking) [10], network parameters and entry strategies of digital firm internationalisation, respectively.

Analysis of our data, guided by this initial framework, leads to identification of the three distinctive features of international expansion by digital firms. Propositions aligned to these characteristics are developed in the remainder of this section technologicalinfrastructure-based

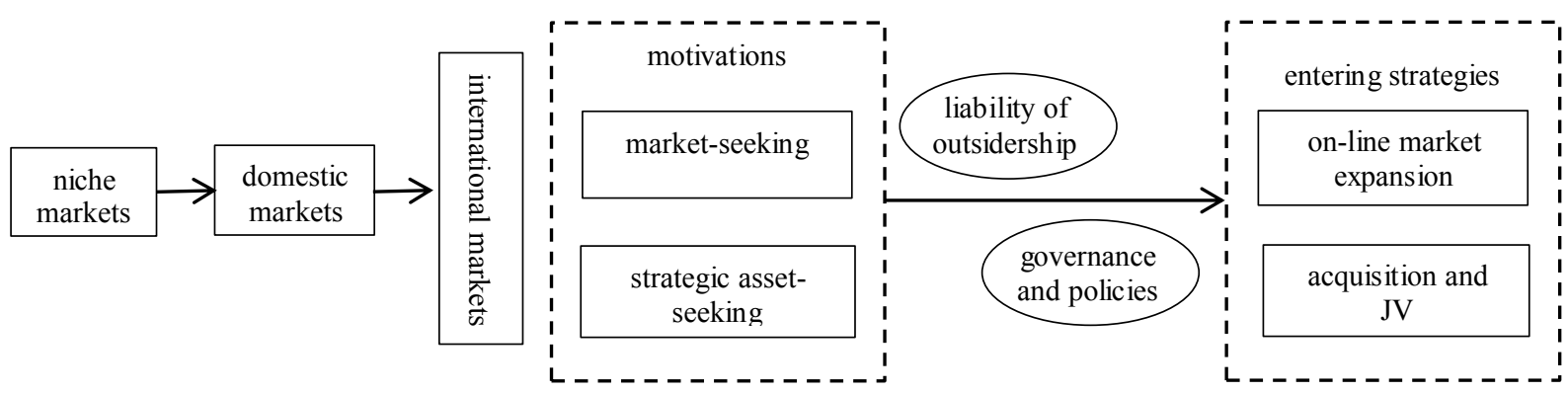

Figure 1: Conceptual framework of digital firms' internationalization path

\subsection{From niche markets to international markets}

The driving force of international expansion for conventional brick-andmortar firms is to reduce transaction costs and achieve internalisation advantage by enlarging production/sales scale in foreign markets $[3 ; 10]$. Thus, the international expansion path of non-digital firms is based on the ability to finance scale and expansion to a few concentrated locations. In contrast, digital firm expansion can benefit from a long tail economy - the ability to reach a small, but highly engaged target market or customer segment with a customized product or service - resulting in lower barriers in terms of scale required for expansion $[17 ; 21 ; 22 ; 25]$. The notion of a long tail economy suggests that new technology allows digital firms to realise significant profits by selling hard-to-find niche items to many geographically dispersed customers, instead of only selling larger volumes of more standardised offerings at a few concentrated locations. Therefore, the international expansion path of digital firms differs from brick-andmortar firms. Thus, we develop our first proposition, albeit rather tentatively, as follows:

Proposition 1: Digital firms internationalise through niche markets.

\subsection{Centralised distribution and uneven location choice}

An observed general pattern of foreign direct investment in the last several decades is the increasing importance of the emerging and developing countries, both as the destinations as well as sources of investment flows [13]. MNEs enter and expand into emerging and developing countries to penetrate new markets, to gain access to various natural resources and to improve production efficiency through cost reduction. However, the findings from our 
study show that this pattern seems less relevant in the case of digital firms.

First, there is an unbalanced distribution of large digital firm headquarters, which are highly concentrated in the developed countries, and the United States in particular. Based on the data from UNCTAD [28], 63 of the top 100 digital MNEs were headquartered in the US, with the remainder mostly from other developed countries and several from China. This uneven distribution is in sharp contrast to leading non-digital MNEs, of which only 19 out of the top 100 were based in the US. The US is clearly a trendsetting 'high-clout' country leading development of digital firms, with China leading the emerging and developing country group.

Second, location choice of digital MNE subsidiaries abroad is also overwhelmingly focused on developed countries. Table 2 lists the three largest international markets for each of the 25 digital firms [28] based on sales or operating revenues in 2015. Cross tabulation analysis revealed that only six among the 108 listed markets were emerging or developing countries.

Thus, it is evident that investment by large digital MNEs is disproportionally distributed in developed countries. This pattern of international expansion of digital MNEs strikingly different from that of nondigital MNEs, who are typically older, follow more traditional business models and thus are more likely to be in the latter stages of international expansion (i.e., from developed to emerging countries). In contrast, digital firms tend to be younger with higher reliance on digital technologies and infrastructure, thus favouring developed countries. Furthermore, while digital firms may suffer from liabilities of outsidership given the existence of boundedness for network effects, such liabilities can be mitigated by the diffusion of digital technologies and development of the digital economy in markets with higher digital clout [7]. However, emerging and developing countries (perhaps with the exception of China) still lag far behind developed countries in generating and applying cutting-edge digital technologies. Thus, digital firms tend to not only originate from but also expand internationally into developed countries. Therefore, we put forward the following proposition:

Proposition 2: Digital firms internationalise primarily into developed markets.

\subsection{Fast expansion with light assets}

Our analysis based on data from the UNCTAD World Investment Report [28] revealed that among the top 100 MNEs in the world, the number of digital firms had more than doubled from four in 2010 to ten in 2015, suggesting a faster international expansion of digital firms than the brickand-mortar MNEs. However, the ratio of foreign assets to foreign sales was lower for digital firms than that of the MNEs in traditional industries. Further, this ratio for digital firms reduced from 0.72 in 2015 to 0.56 in 2017. Rapid development of the global digital economy, digital technologies, and their derived infrastructure, such as the internet and various digital platforms, has enabled digital firms to gain foreign sales with relatively lower ratio of foreign assets and facilitated the faster international expansion of digital firms.

Digital firms have a high reliance on the internet for their operations and product/service offerings. Due to the characteristic of being 'virtual-permeated', digital firms can reach their end customers much faster compared with traditional brick-and-mortar firms [6]. Therefore, there is high potential for digital firms to leapfrog the stages of internationalisation, quickly moving from domestic base into international markets. As a result, traditional barriers faced at country borders and liability of foreignness can be mitigated to a large extent. Relying on digital technologies, digital firms can operate mainly from a home country base but directly reach end customers both at home 
and foreign markets (particularly those that offer software as a service). As a result, international expansion of digital firms is faster than brick-and-mortar firms. Thus, we put forward our third proposition as follows:

Proposition 3: Digital firms tend to internationalise earlier, faster and using fewer resources.

\section{Theoretical and managerial implications}

This study investigated international expansion by digital firms in the modern digital economy. Specifically, we argue their internationalisation path derives from their unique characteristics, which presents a challenge to traditional internationalisation theory. Our research findings suggest that due to the network effects and the long tail economy generated by digital technologies, digital firms are able to capture highly specified niche markets by connecting geographically scattered users through online networks. Moreover, the findings from our study demonstrate that the international expansion path of digital firms presents a quite different picture from that predicted by the mainstream stages (Uppsala) model $[9 ; 14]$.

First, the findings suggest that in contrast to conventional brick-and-mortar firms, international expansion of digital firms is not determined by the firm's resource commitments to foreign markets but relies more on the users' collective interaction and development of the digital infrastructure of international markets. Similar to network-based entities, the firm is longer the sole agency involved in and orchestrating international expansion, nor is international expansion fully determined by the external users of the products/services that are provided by digital firms.

Second, rapid growth of the digital economy has enabled geographic boundedness and associated liability of foreignness to be greatly mitigated by the emergence of international networks, which are facilitated by digital technologies. However, digital firms may still suffer liability of outsidership due to the boundedness of international network effects, resulting in a winners-take-all outcome.

Third, unlike the traditional brick-andmortar firms that rely on scale economies to establish competitive advantage, digital firms internationalize from a niche market position and rely on rapid penetration into targeted foreign markets with only light asset involvement. Due to the even shorter product life cycles and the unprecedented speed of information sharing in the digital era, not only is the risk of duplication by competitors much higher, but also the chances of being a successful follower much lower.

These findings reinforce the importance of network connectedness to internationalisation [31], but in particular those between otherwise unconnected individuals at the digital level. They also reinforce the importance of niche markets, but not as the domain of the early internationalising 'born global' firms typically associated with such strategies, but global technologically driven giants that rapidly transform such niches to the new normal (e.g., Uber).

For businesses operations based on digital technologies, seeking international opportunities by exploring foreign markets is crucial for survival and growth. Given the dramatic advancement of digital technologies combined with intensified market competition, business practitioners in the digital business arena are increasingly concerned with 'how' to expand rapidly into foreign markets, perhaps more than 'why' to do so. The findings of this study provide some important insights to executives grappling with the 'how' issues associated with international expansion. International network effects can translate into actionable strategies for international expansion of digital firms. Managerial executives of digital firms should employ a 
staged international expansion approach, not based on the geographic distance or resource commitment, but on the digital 'clout' of the countries. Expanding first into high-clout countries may facilitate participation of influential networks and encourage user recruitment on a much wider stage. Similar to how conventional firms hire and retain the best talent, digital firms need to recruit the right users and expand exponentially from their focused market niche. It is crucial for managerial executives to retain first-mover advantage. Focussed attention on user base, sustainable innovation, identifying new market niches and protection of intellectual property rights is central to success.

\section{References}

[1] Banalieva, E. R., \& Dhanaraj, C. (2019). Internalization theory for the digital economy. Journal of International Business Studies, 50(8), 1372-1387.

[2] Brouthers, K. D., Geisser, K. D., \& Rothlauf, F. (2016). Explaining the internationalization of ibusiness firms. Journal of International Business Studies, 47(5), 513-534.

[3] Buckley, P. J., \& Hashai, N. (2009). Formalizing internationalization in the eclectic paradigm. Journal of International Business Studies, 40(1), 58-70.

[4] Business Insider (2019). Tencentbacked Kai app ranked most popular social short video app. Retrieved from: https://markets.businessinsider.com/news/s tocks/tencent-backed-kwai-app-rankedmost-popular-social-short-video-app1025560745

[5] Cahen, F., \& Borini, F. M. (2020). International digital competence. Journal of International Management, 26(1), 100691. [6] Cassetta, E., Monarca, U., Dileo, I., Di Berardino, C., \& Pini, M. (2020). The relationship between digital technologies and internationalisation. Evidence from Italian SMEs. Industry and Innovation, 27(4), 311-339.
[7] Chen, L., Shaheer, N., Yi, J., \& Li, S. (2019). The international penetration of ibusiness firms: Network effects, liabilities of outsidership and country clout. Journal of International Business Studies, 50(2), 172192.

[8] Chen, W., \& Kamal, F. (2016). The impact of information and communication technology adoption on multinational firm boundary decisions. Journal of International Business Studies, 47(5), 563-576.

[9] Coviello, N., Kano, L., \& Liesch, P. W. (2017). Adapting the Uppsala model to a modern world: Macro-context and microfoundations. Journal of International Business Studies, 48(9), 1151-1164.

[10] Dunning, J. H. (2001). The eclectic (OLI) paradigm of international production: past, present and future. International journal of the economics of business, 8(2), 173-190.

[11] Eden, L. (2018). The fourth industrial revolution: seven lessons from the past. In International Business in the Information and Digital Age (pp. 15-35).

[12] Gabrielsson, M., Fraccastoro, S., Ojala, A., \& Rollins, M. (2021, January). Digital entrepreneurial internationalizers: definitions, theoretical implications, and research avenues. In Proceedings of the 54th Hawaii International Conference on System Sciences, pp. 5069-5078.

[13] Hill, C. W., \& Hult, G. T. (2019). International Business: Competing in the Global Market place. New York: McGraw Hill Education.

[14] Johanson, J., \& Vahlne, J. E. (1977). The internationalization process of the firm - a model of knowledge development and increasing foreign market commitments. Journal of international business studies, 8(1), 23-32.

[15] Li, J., Chen, L., Yi, J., Mao, J., \& Liao, J. (2019). Ecosystem-specific advantages in international digital commerce. Journal of International Business Studies, 50(9), 14481463.

[16] Monaghan, S., Tippmann, E., \& Coviello, N. (2020). Born digitals: Thoughts on their internationalization and a 
research agenda. Journal of International Business Studies, 51(1), 11-22.

[17] Nambisan, S. (2017). Digital entrepreneurship: Toward a digital technology perspective of entrepreneurship. Entrepreneurship Theory and Practice, 41(6): 1029-1055.

[18] Nambisan, S., Zahra, S. A., \& Luo, Y. (2019). Global platforms and ecosystems: Implications for international business theories. Journal of International Business Studies, 50(9): 1464-1486.

[19] Ojala, A., Evers, N., \& Rialp, A. (2018). Extending the international new venture phenomenon to digital platform providers: A longitudinal case study. Journal of World Business, 53(5), 725-739.

[20] Ojala, A., Rollins, M., Fraccastoro, S., \& Gabrielsson, M. (2020). The internationalization of $\mathrm{B} 2 \mathrm{~B}$ digital platform providers: The Role of cross-national distance and digital characteristics. In Proceedings of the Annual Hawaii International Conference on System Sciences. University of Hawai'i at Manoa, pp. 4652-4661.

[21] Parente, R. C., Geleilate, J.-M. G., \& Rong, K. (2018). The sharing economy globalization phenomenon: A research agenda. Journal of International Management, 24(1): 52-64.

[22] Parker, G., van Alstyne, M., \& Jiang, X. (2017). Platform ecosystems: How developers invert the firm. MIS Quarterly, 41(1): 255-266.

[23] Shaheer, N. A., \& Li, S. (2020). The CAGE around cyberspace? How digital innovations internationalize in a virtual world. Journal of Business Venturing, 35(1), 105892.

[24] Stallkamp, M., \& Schotter, A. P. (2021). Platforms without borders? The international strategies of digital platform firms. Global Strategy Journal, 11(1), 58-80.
[25] Teece, D. J. (2018). Profiting from innovation in the digital economy: Enabling technologies, standards, and licensing models in the wireless world. Research Policy, 47(8): 1367-1387.

[26] Ting, A., \& Gray, S. J. (2019). The rise of the digital economy: Rethinking the taxation of multinational enterprise. Journal of International Business Studies, 50(9): 1656-1667.

[27] Tomelin, J., Amal, M., Zen, A. C., \& Arrabito, P. (2018). Internationalisation of science parks: Experiences of brazilian innovation environments. In In $\mathrm{R}$. van Tulder, A. Verbeke, \& L. Piscitello (Eds), International Business in the Information and Digital Age (vol. 13, pp. 391-408).

[28] UNCTAD. (2017). World Investment Report 2017: Investment and the digital economy. United Nations Conference on Trade and Development, United Nations, Geneva.

[29] UNCTAD. (2019). Digital Economy Report 2019. United Nations Conference on Trade and Development, United Nations, Geneva.

[30] Vadana, I. I., Torkkeli, L., Kuivalainen, O., \& Saarenketo, S. (2019). Digitalization of companies in international entrepreneurship and marketing. International Marketing Review, 37(3): 471-492.

[31] Vahlne, J. E., \& Johanson, J. (2020). The Uppsala model: Networks and microfoundations. Journal of International Business Studies, 51: 4-10.

[32] Wu, X., \& Gereffi, G. (2018). Amazon and Alibaba: Internet governance, business models, and internationalization strategies. In R. van Tulder, A. Verbeke, \& L. Piscitello (Eds), International business in the information and digital age (vol. 13, pp. 327-356). London: Emerald. 